Monthly Progress Report

\title{
Building Thermal Envelope Systems and Materials (BTESM) and Research \\ Utilization/Technology Transfer Progress Report for DOE Office of Buildings Energy Research
}

August 1990

Compiled by Gabrielle Burn for

Jeffrey E. Christian, Program Manager Energy Division

Prepared by the Oak Ridge National Laboratory

Oak Ridge, Tennessee 37831 operated by

Martin Marietta Energy Systems, Inc.

for

U.S. DEPARTMENT OF ENERGY

under contract DE-AC05-840R21400 
CONTENTS

I. BUILDING THERMAL ENVELOPE SYSTEMS AND MATERIALS (BTESM) Page

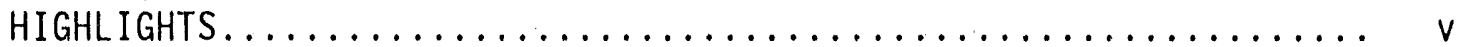

ABSTRACT..................................... vi

A. IMPLEMENTATION

1. Administration/Technical Support/Selected Projects....... 1

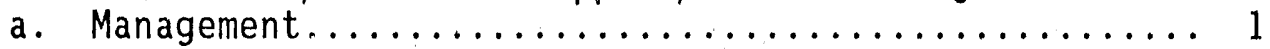

b. Reports Published This Period................. 3

c. Conferences and Meetings of Interest.............. 4

d. Consultants Report........................ 6

B. BUILDING MATERIALS PROGRAM

Task B1. Advanced Materials Research

1. Alternative Materials for CFC-Based Foam Insulations..... 8

2. Thermal Resistance Measurements and Data Base of CFC-Replacement Thermal Properties for Foam

Insulation Products........................... 10

3. Investigation of the Substitution of Environmentaliy Acceptable Blowing Agents in Foam Insulation: Means to

Achieve Equivalent or Approved Energy Efficiency........11

Task B2. Performance of Currently-Used Materials

1. Models, Methods, Measurements................... 12

2. Thermal Insulation Studies....................... 13

3. Standard Reference Material Development............... 14

4. Residential Insulation Corrosiveness................... 14

5. Residential Insulation Corrosiveness/Consultant's

Report................................... 15

6. Research and Development Data to Define the Thermal Performance of Reflective Materials Used to Conserve

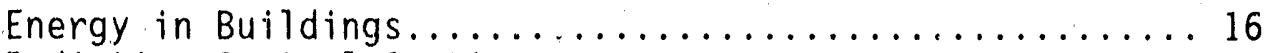

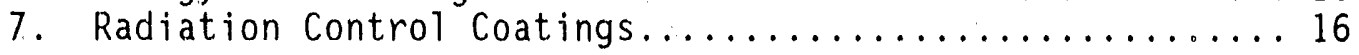

Task B3. Building Materials Program Management Support

1. Support Activity........................ 17

C. BUILDING ENVELOPE SYSTEMS

WALL PERFORMANCE

1. Thermal Mass Simplified Design Tool Assessment......... 20

2. Dyriamic Evaluation of Thermal Bridges............... 21

3. Validation of Moisture-Transfer Model............... 23 
C. BUILDING ENVELOPE SYSTEMS (cont'd)

\section{ADVANCED WALL SYSTEMS}

1. Moisture Control Handbook..................... 24

\section{FOUNDATION SYSTEMS}

1. Building Foundations Research Agenda............. 25

2. Slab Foundation Benchmark Mode1................... 25

3. Foundation Thermal Performance Simplified

Prediction Tool.

ROOF SYSTEMS

1. Roofing Research Center..................... 27

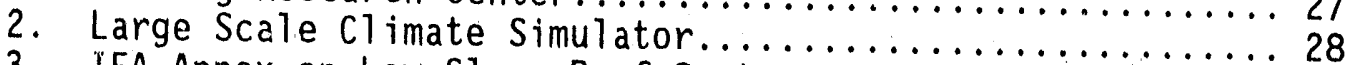

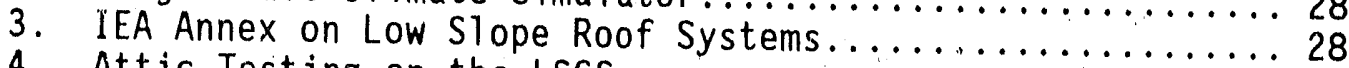

4. Attic Testing on the LSCS..................... 29

5. Field Testing of Isocyanurate Foams with Aiternate Blowing Agents.............................. 30

6. Roof Mechanical Properties Research Apparatus.................. 31

7. Roofing Industry Committee on Wind Issues............. 31

D. COOPERATIVE PROJECTS

1. Cooperative Industry/Government Research Project on Alternative Blowing Agents...................... 33

DIRECTORY OF PRINCIPAL INVESTIGATORS $\ldots \ldots \ldots \ldots \ldots \ldots \ldots \ldots \ldots \ldots$

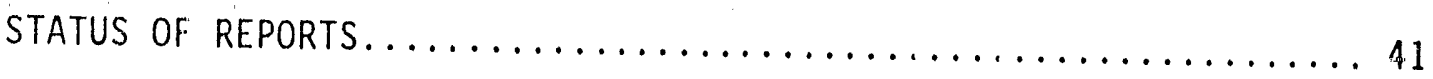

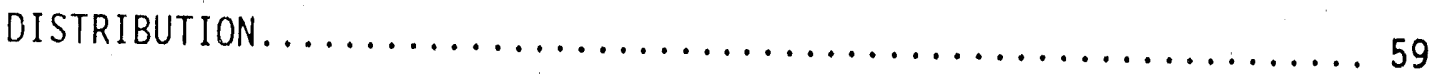




\section{HIGHLIGHT}

The following sections are puilished in the back of this month's report:

Director of Principal Investigators

Status of Reports

Distribution List

These will be published every February and August. 


\section{HIGHLIGHT}

\section{SECOND SYMPOSIUM ON INSULATION MATERIALS-- TESTING AND APPLICATIONS}

October 10-12, 1991

Gatlinburg, Tennessee

\section{SPONSORED BY ASTM COMMITTEE C16 ON}

\section{THERMAL INSULATION}

Call for Papers:

Abstracts Due:

April 1, 1990

Abstract Acceptance Notification:

August 1, 1990

Manuscripts Due:

STP Available:

January 1, 1991

October 10, 1991

For more information, please contact Symposium Co-Chairmen:

Ron S. Graves

Oak Ridge National Laboratory

Post Office Box 20)8

Building 4508

Oak Ridge, TN 37831-6092

615/574-5978

FAX 615/574-7721
Don C. Wysocki

Mobay Corporation

Penn Lincoln Parkway West

Pittsburgh, PA 15205

412/777-2574

FAX 412/777-2758 
Building Thermal Envelope Systems and Materials (BTESM) Progress Report for DOE Office of Buildings Energy Research

\section{ABSTRACT}

The Monthly Report of the Building Thermal Envelope Systems and Materials (BTESM) Program is a monthly update of both in-house ORNL projects and subcontract activities in the research areas of building materials, wall systems, foundations, roofs, building diagnostics, and research utilization and technology transfer. Presentations are not stand-alone paragraphs every month. Their principal values are the short-time lapse between accomplishment and reporting and their evolution over a perind of several months. 


\section{BUILDING THERMAL ENVELOPE SYSTEMS AND MATERIALS (BTESM)}

\section{A. IMPLEMENTATION}

\section{Administration/Technical Support/Selected Projects}

This task includes overall management for the BTESM Program with the emphasis on assuring that individual R\&D projects are performed via the best available expertise whether it be at universities, private labs, professional associations, or national labs (including ORNL). Also included are: implementation of major conferences, workshops and seminars, assurance of BTESM staff participation in committee work (BTECC, NIBS, ASTM, ASHRAE, etc.), BTESM National Program planning jointly with the total building community, technical support to DOE, and oversight of selected technical projects not delegated to other tasks.

\section{a. Management (Jeffrey E. Christian/Pat M. Love, ORNL)}

The CFC Cooperative Research Project was given considerable attention at this years annual Energy Division Information meeting held August 20-23, 1990. Comments made by John Cuttica, GRI, were extremely favorable. He felt that it is exactly the type of work a National Laboratory ought to be doing. "The thermal measurement capabilities here make ORNL uniquely qual ified to help address the technical viability of alternative blowing agents for CFCs." He indicated that the objectives and ultimate products to come from this work were well defined. He liked the fact that private industry was a major participant, which assures technology transfer of the research.

BTESM Staff provided a technical briefing to Alvin Trivelpiece, ORNL Director, and his Executive Committee on August 8, 1990, on Attic Thermal Performance Testing in the Large Scale Climate Simulator. One comment was that since this work was done with joint sponsorship we should publish the results quickly. Our response was that we are a national user facility and that we first are sharing our preliminary findings with insulation manufacturers who will provide a strong technical review of work thus far. Secondly, we are hopeful that several insulation manufacturers will work closely with ORNL to enhance our ability to provide even more efficient cost effective attic systems.

Some follow-up work is beginning to come into the Roof Research Center on attic testing. A contract with the cellulose industry has been initiated to have cellulose tested in the LSCS attic test module. A draft work statement has been sent to MIMA at their request to consider testing batts, rockwool, and several other fiberglass blown insulations.

A11 program areas are currently planning budgets for FY 1991. The budget levels are down from FY 1990. This in itself will cause some cutbacks in overall projects. However, the main concern is the 
proposed $32 \%$ Gramm-Rudman cut, imposed on a11 programs if Congress and the Administration do not develop an acceptable deficitreduction agreement. DOE Energy Secretary James Watkins has directed all programs to take immediate action to limit operating costs in case the sequestration does occur on october 1.

Pat Love briefed Donna Hawkins, DOE/HQ, last month on the technology transfer industry relations. Hawkins witnessed the industry participation on the roof installation on the ESRA while visiting Oak Ridge. Hawkins gave us a good write-up in the DOE weekly accomplishments notes to Millhone.

\section{EVENTS}

August 2

Jeff Christian attended a final review meeting of the Builders Foundation Handbook at DOE/HQ in Washington, D.C. This meeting was led by Sam Taylor, DOE Program Manager for Foundations Research.

August 3

Jeff Christian chaired a Moisture Control Handbook meeting at NIBS in Washington, DC

August 8

J. E. Christian presented a BTESM overview to Ted Kurkowski and Marvin Gorelick of DOE/HQ

Facilities Systems Division. This included a tour of the Roof Research facilities.

August 8

Jeff Christian presented a technical briefing on attic testing in the Large Scale Climate Simulator to Alvin Trivelpiece, ORNL Laboratory Director, and his Executive Committee.

August 13

Pat Love met with Marvin Gorelick and discussed possible facilities support for the RRC. He said there was a possibility of some support.

August 14

Pat love met with Jim Smith in Washington, D.C., to discuss the implementation program budget. This included support for the fifth. Thermal Envelope conference. Support was guaranteed and plans are in the making for the conference to be held in December 1992.

August 21

Bob Wendt and Jeff Christian held a poster session and provided a tour of the Roof Research Center and Foundation Test Facilities to the entire Energy Division Advisory Panel. 
August 21

Jeff Christian provided a techrical highlight to three members of the Energy Division Advisory Panel, John Cuttica, GRI, Bruce Buchanan, University of Pittsburgh, and Mart in Williams, Northern Illinois University.

August 21

H. Alan Fine, University of Kentucky, visited ORNL.

August 22

D. Wysocki, Mobay, visited ORNL.

August 29

Bob Wendt and Jeff Christian provided a tour of the Roof and Foundation Test Facilities to ORNL Associate Directors David Reichle and Bill Fulkerson, and several members of the Oak Ridge Chamber of Commerce visiting the Laboratory with Senator Sasser.

\section{b. REPORTS PUBLISHED THIS PERIOD}

None. 


\section{c. CONFERENCES AND MEETINGS OF INTEREST*}

$\underline{1990}$

Sepiember 3-6: International Symnosium on Energy, Moisture, Climate in Buildings, sponsored by CIB International Council of Building Research, to be held in Rotterdam, The Netherlands.

September 26-28: ICAA 12th Annual Convention/Expo, sponsored by the Insulation Contractors Association of America, to be held at the walt Disney World Swan Hotel in Orlando, Florida. For more information, contact R. Hartley Edes, ICAA, 15819 Crabbs Branch Way, Rockville, MD 20855, or cal1 (301) 590-0030.

September 30-October 3: 33rd Annual Polyurethane Conference, sponsored by The Society of the Plastics Industry, Inc., to be held at Marriotts Orlando World Center Resort and Convention Center in Orlando, Florida. For more information, contact SPI, 355 Lexington Avenue, New York, NY 10017, or ca11 (212) 351-5425, TELEX: 12029, FAX (212) 697-0409.

October 14-17: ASTM C 16 Fall Meeting, Omni Royal, New Orleans, Louisiana.

October 23-26: Leaking Underground Storage k'orkshop, co-sponsored by the Environmental Sciences and Technology Division of the Georgia Tech Research Institute and the United States Environmental Protection Agency. The workshop will be held on the Georgia Tech campus in the Space Science Building. For more information, contact the training programs office at (404) 894-3806.

October 25-26: ASTM Symposium on Water In Exterior Building Walls: Problems and Solutions, to be held in Dearborn, Michigan. More information is available from Symposium Chairman Thomas A. Schwartz, Simpson Gumpertz \& Heger, Inc., 297 Broadway, Arlington, MA 02174, (617) $643-2000$.

December 10-12: Third Brazilian Thermal Science Meeting, ENCIT-90, to be held in Itapema, SC, Brazil. For more information, contact Professor Alvaro T. Prata, Department of Mechanical Engineering, Federal University of Santa Catarina, P.0. Box 476, 88049 - Florianopolis-SC, Brazil, or call (0482) 335166, FAX (0482) 331519, or Telex 481317 FUEG BR.

$\underline{1991}$

January 19-23: ASHRAE 1990 Winter Meeting, to be held in New York, NY. For more information, contact Judy Marshall or Jan Young, ASHRAE Meetings, 1791 Tullie Circle, NE, Atlanta, GA 30329, or call (404) $636-8400$.

*Please send notices to Gabrielle Burn. 
Apri1 17-19: Third International Symposium on Roofing Technology, sponsored by the National Institute of Standards and Technology; U.S. National Roofing Contractors Association; Canadian Roofing Contractors Association; National Research Council of Canada; International Waterproofing Association; CIB, and RILEM. The symposium will be held at the Montreal Convention Centre, Montrea1, Quebec, Canada. For more information, contact Walter Rossiter, NIST, Center for Building Technology, Building 226, Room B-348, Gaithersburg, MD 20899, or cal1 (301) 975-6719, FAX (301) 975-4032, TELEX TRT 197674 NIST WT.

October 10-12: Second Symposium on Insulation Materials--Testing and Applications, sponsored by ASTM Committee C 16, to be held in Gatl inburg, TN. For more information, contact Symposium Co-Chairmen: Ron S. Graves, Oak Ridge National Laboratory, P.0. Box 2008, B1dg. 4508, Oak Ridge, TN 37831-6092, (615) 574-5978; or Don C. Wysocki, Mobay Corporation, Penn Lincoln Parkway West, Pittsburgh, PA 15205, (412) $777-2574$.

\section{$\underline{1992}$}

December: Therma1 Performance of the Exterior Envelope of Buildings $V$, to be held in the Florida area. Sponsors include DOE, ASHRAE, and BTECr. For more information, contact Pat M. Love, Co-Chairperson, Oak Ridge National Laboratory, P.0. Box 2008, Oak Ridge, Tennessee 37831-6070, or cal1 (615) 574-4346. 
d. CONSULTANTS

\author{
ACEC RESEARCH AND MANAGEMENT FOUNDATION \\ Jack R. Warner \\ President \\ Washington, D.C. 20005 \\ Subcontract ORNL/SUb-SE077/3 \\ Deliver by: 05-31-90
}

A new contract is pending.

\author{
BTECC WORKSHOPS AND FEASIBILITY STUDY \\ BUILDING THERMAL ENVELOPE COORDINATING COUNCIL \\ NATIONAL INSTITUTE OF BUILDING SCIENCES \\ Bruce E. Vogelsinger \\ National Institute of Building Sciences \\ Washington, D.C. 20005 \\ Subcontract ORNL/Sub-SC111/6 \\ Deliver by: $12-31-90$
}

No report. 


\section{TASK B. BUILDING MATERIALS PROGRAM}

The Building Materials Program includes work done at ORNL and work done by others on DOE-funded projects. The following pages include project reports for three areas:

\section{B1. ADYANCED MATERIALS RESEARCH}

Cooperative Government/Industry Project on Alternatives for CFC-Based Foam Insulation High-Resistance Powder-Filled Evacuated Panels

B2. PERFORMANCE OF CURRENTLY-USED MATERIALS

Determination of properties of materia?s. impruvement of test procedures

B3. MATERIALS PROGRAM MANAGEMENT SUPPORT

Technology transfer

Cocrdination of subcontracted research 
BUILDING

MATERIALS

PROGRAM

TASK B1. ADVANCED MATERIALS RESEARCH

\title{
1. ALTERNATIVE MATERIALS FOR CFC-BASED FOAM INSULATIONS
}

\author{
D. L. McElroy, R. S. Graves, T. G. Kollie, and D. W. Yarbrough \\ Oak Ridge National Laboratory \\ 0ak Ridge, Tenriessee 37831-6092
}

This task is currently focused on two topics:

(1.1) The Cooperative Government/Industry Research Project for CFC Alternatives, and

(1.2) High-Resistance Powder-filled Evacuated Panels (PEPs)

1.1 Cooperative Project. We reviewed the first draft of an ORNL/TM entitled, "Thermal Resistance of Polyisocyanurate Foam Board Insulation Blown with CFC-11 Substitutes." The second draft will be prepared for DOE/HQ as a FY 1990 deliverable due in September 1990. The draft recommends that the thin-specimen procedure be applied to other types of foam insulation, to the next gerieration of polyisocyanurate foams with improved structural characteristics, and to panels in the Roof Test Research Apparatus. We prepared viewgraphs for a talk at the University of Tennessee entitled, "Alternate Blowing Agents for Foams."

We circulated a letter report to the participants on the interlaboratory comparison of apparent thermal conductivity measurements at $75^{\circ} \mathrm{F}$ on two rigid polyisocyanurate boards, and as a pair, using four 24 in. by 24 in. comparativ eat flow meter apparatuses that meet ASTM C 518. The imprecision, defined as two standard deviations, was less than that found for a glass fiber blanket in the 1987 ASTM C 687 round robin. This suggests that future tests should include test specimens with greater thicknesses.

We obtained the MIT computer program for aging and modified it for use at ORNL at MITB. MITB and programs to calculate the $k$ of gas mixtures provided predictions of long-term foam behavior with alternate permeability values, as a function of board thickness, and for alternative initial blowing agent gas pressure. This showed the need to develop a three-dimensional model to assess aging of faced foams. 
1.2 Panels. We visited General Electric (GE) Appliance Park in Louisville to perform an intercomparison of their method of measuring the internal pressure of a panel and the method we have recently developed. Unacceptably large differences were reveaied by this test. Some of our measurements were up to a factor of two larger than theirs. Because their method can not be calibrated and our device has been calibrated on a panel film below which there was a known pressure and on an absolute basis as well, we have attributed the differences to errors in their measurement technique.

The GE device was originally developed for them by Babcock and Wilcox. (B\&W). Prior to this intercomparison, the pressure in some of the panels had been measured by Global Thermionics. Global's measurements, which were made with a later model of the $B \& W$ device, were as much as a factor of three lower than GE's.

We called $B \& W$ and discussed this problem with them. We were referred to the engineer who developed the device for GE in 1987. He said that the during development, the emphasis was on repeatability, not accuracy, and that the vacuum gauge used is recommended in the $1 \times 10^{-2}$. Torr to 1 Torr range, which is much beluw that used in the measurements on our panels. B\&W used the manufacturers calibration of the vacuum gauge; it was not calibrated on an absolute basis by them. Also, they did not know the absolute pressure inside any of the panels supplied by GE to them during the development work on the device; they only were given a pressure range. In addition, a "look-up table" is employed by the computer software of the B\&W device to determine the pressure from the voltage output of the vacuum gauge; linear interpolation is used, but the voltage is an exponential function of pressure and is very insensitive in the range of pressures of interest. Also, the engineer believes that the dynamic mode of operation of the $B \& W$ device leads to pressure measurements that are too low. Slow evacuation would be better as is done in our technique, but the GE specification required a one minute turn around time on the measurement; thus, the dynamic mode was mandated.

Much of the present technology of powder evacuated panels is based on the pressure measurements with the B\&W device. The importarice of this fact can be seen from three examples. If the $B \& W$ device is used to determine the pressure dependence of the thermal resistance $(R)$ of panels, the results would predict too high a decrease in $R$ with pressure. On the other hand, pressure rise measurements versus time to determine the permeability of the panel's barrier film, would predict too low a permeability. A third consequence of the errors in pressure measurement would be errors in predictions of the useful lifetime of panels. 


\title{
2. THERMAL RESISTANCE MEASUREMENTS AND DATA BASE OF CFC-REPLACEMENT THERMAL PROPERTIES FOR FOAM INSULATION PRODUCTS
}

\author{
R. Zarr \\ National Institute of Standards and Technology \\ Gaithersburg, Maryl and 20899
}

ORNL/IA-21513/25

\section{Progress Report for July 1990:}

Task A, Milestone 5 (Measure Materials on GHP and HFM): Two moro specimens of polyisocyanurate foam insulation having permeable organic/ inorganic facers were measured on the following three apparatuses: the NIST one-meter guarded hot plate, the 610 millimeter heat-flow-meter (HFM) apparatus, and the 305 millimeter HFM. The thickness of each specimen was about 125 and 163 millimeters, respectively. Botn specimens were comprised of stacked boards, 37.5 millimeters in thickness. Measurements of apparent thermal conductivity were conducted at a mean specimen temperature of $24^{\circ} \mathrm{C}$ with a temperature difference of $22^{\circ} \mathrm{C}$ across the specimen. Prior to measurement, the two heat-flow-meter apparatuses were calibrated using specimens of fibrous ylass board conditioned at $90^{\circ} \mathrm{C}$ ard having a density of 138 kilograms per cubic meter.

Miscellaneous:

1. As described in June's monthly progress report, a time-state model had been developed to investigate the dynamic responses of the guarded hot plate. An upgrade to the control software for the NIST one-meter guarded hot plate was completed. The upgrade controls the apparatus using an incremental PI control algorithm. Validation of the model is now under way in parallel with the measurements described above.

2. The paper entitled, "Summary of Low-Density Glass-Fiber Peference Materials at NIST: 1989-1989," has been accepted by the Journal of Thermal Insulation. Comments from outside reviewers have been added and a revised copy of the paper will be sent to the editor.

3. The large environmental chamber has been returned from the manufacturer after upgrade. The upgrade includes humidity and dynamic temperature control. Acceptance tests are in progress.

4. Four specimens of cellulose loose-fill insulation were prepared with assistance of the National Association of Home Builders (NAHB). Specimens will be measured as part of the 1990. ASTM C 687 Round Robin. 
Task B. Milestone 3 (Measure New Foam Products): As discussed in June's progress report, NIST will participate in a series of small round robins with ORNL and JWRC. Two foam boards blown with a refrigerant-11 were received from ORNL via JWRC on July 16, 1990. The thickness and apparent thermal conductivity of each board was measured separately and then stacked. The apparent thermal conductivity was determined using the $610 \mathrm{~mm}$ heat-flow-meter apparatus (ASTM C 518). Results were tabulated and reported to ORNL.

\title{
3. INVESTIGATION OF THE SUBSTITUTION OF ENVIRONMENTALLY ACCEPTABLE BLOWING AGENTS IN FOAM INSULATION: MEANS TO ACHIEVE EQUIVALENT OR APPROVED ENERGY EFFICIENCY
}

\author{
Gl icksman, Burke, Lanciani, Mozgowiec, Page \\ Massachusetts Institute of Technology \\ Cambridge, Massachusetts 02139
}

ORNL/SUB -09099/15

Quantitative FTIR spectrometry tests of various candidate powders are under way using the pellet technique. Pycnometer tests of these samples are also under way to find true densities of these samples. Combined results of these tests will determine the relationship between percent transmission and average transmissivity of radiant energy through the sample versus the mass of the sample. Mechanofusion processing of core materials such as ground PU foam, PPO powder, and PMMA powder with coatings of $A 1, C$, and Co will soon take place courtesy of the Micron Powder Systems company in New Jersey.

A summary of research in foam insulation was presented at the Gordon Conference on Foams in Plymouth, New Hampshire. The projects presented included studies on reducing radiation heat transfer, permeability tests of alternate blowing agents, and the inclusion of vacuum panels within the foam board.

Two different methods of reducing radiation heat transfer were proposed: cell size reduction and the addition of highly reflective flakes to the foam mix. 


\section{BUILDING \\ NATERIALS \\ PROGRAM}

\section{TASK B2. PERFORMANCE OF CURRENTLY-USED MATERIALS}

\section{MODELS, METHODS, MEASUREMENTS - ORNL}

This task is currently focused on three topics:

1. Development and use of analytical models for heat transfer.

2. Development and use of flat insulation testers: the Unguarded Thin Heater Apparatus (UTHA) and the Advanced R-Matic Apparatus.

3. Measurement of the behavior of 100 se-fill attic insulation.

\subsection{Models-ORN!}

A finite difference model for analyzing transient data from the Unguarded Thin-Heater Apparatus was used to describe the impact of ratio of the heater and specimen thermal masses. For large values of this ratio the temperature response of the heater is delayed. A correlation with thermal mass ratio was developed as an alternative to analyzing transient data assuming a zero thermal mass ratio. We obtained a stainless steel screen with only $25 \%$ of the thermal mass of the present Nichrome heater and we plan to test this as a means to obtain reduced thermal mass ratio.

\subsection{Methods -ORNL}

We reviewed the first draft of an ORNL/TM entitled, "SteadyState and Transient. Results using the Unguarded Thin-Heater Apparatus (UTHA). The revised text is being typed for DOE/HQ as a FY 1990 deliverable in September 1990. We ordered a high capacity controlled temperature circulating bath to lower the operating temperature of one bounding plate to below $50^{\circ} \mathrm{F}$. This would extend the UTHA operating range.

The ORNL Advanced R-Matic was used to measure $k$ with heat flow up and down for insulation specimens prepared at Lawrence Berkeley Laboratory. A second letter report is being prepared to describe this second set of measurements.

\subsection{Loose-Fill Attic Insulation-ORNL}

In August we completed thermal tests on cellulosic insulation and initiated tests on poured perlite and blown rockwool for the 1990 ASTM C 687 Interlaboratory Comparison on the Thermal Resistance of Loose-fill Insulations. 
We completed and submitted to DOE/HQ the second draft of a report entitled, "1990 Loose-Fill Insulation Interlaboratory Comparison Test Plan." This report was submitted to the Records Office to prepare an ORNL Central Files Memo. This report recommends that the specimen preparation facility be used in a couperative program to determine real in-service thermal performance of 100 se-fill insulations.

\section{THERMAL INSULATION STUDIES}

D. H. Yarbrough, S. Wudhapitak, and M. Said Department of Chemical Engineering Tennessee Technological University Cookeville, Tennessee 38505

ORNL/SUb - 7715/90

No progress to report for the month of August. 


\title{
3. STANDARD REFERENCE MATERIAL DEVELLPMENT
}

\author{
D. R. Smith \\ Chemical Engineering Science Division \\ National Institute of Standards and Technology \\ Boulder, Colorado 80303-3328
}

ORNL/IAA-21428/63

We obtained a NISTIR report on the thermal conductivity of a polyamide film between 4.2 and $300 \mathrm{~K}$ with and without alumina particles as a

filler.

\section{RESIDENTIAL INSULATION CORROSIVENESS}

\author{
E. E. Stansbury \\ Consultant \\ 5800 Woodburn Drive \\ Knoxville, Tennessee 37919 \\ ORNL/SUb-B8240/28
}

The corrosion rate meters (Corrater) being used in the ASTM round robin program to evaluate an electrochemical method for assessing the corrosiveness of residential building thermal insulation have been forwarded to the last of eight participants. Participants have been urged to report the results of their measurements on the thirteen designated environments as soon as possible to permit reporting to the ASTM 16.31 Corrosion Task Group at the meeting in October. 


\title{
5. RESIDENTIAL INSULATION CORROSIVENESS
}

\author{
E. E. Stansbury \\ Materials Science and Engineering Department \\ University of Tennessee \\ Knoxville, Tennessee 37919 \\ Martin Marietta Energy Systems, Inc. \\ 99732PAX/12 \\ Consultant's Report
}

Studies have continued on development of a method of comparing the corrosiveness of wet residential building thermal insulations using partially immersed steel samples in wet insulation. Previous work had shown that this mode of exposure allowed assessment of both the effects of leachable species from the insulation and the effect of oxygen from air. Low carbon steel sheet, 0.003 in. thick, is being used to duplicate the thickness specified by ASTM 739. The specimens are 2 in. $x 2$ in. placed vertically in $5 \mathrm{~cm}$ deep crystallizing dishes. Wet insulation, $4 \mathrm{~cm}$ deep, is packed around the specimens and distilled water added (and maintained) until visible at the top of the insulation. The criterion for failure of the test in ASTM 739 is perforation of the sheet after 336 hours of exposure at $120^{\circ} \mathrm{F}$. In the current investigation, exposure is at room temperature with the criterion for failure being perforation of the sheet in the vicinity of the wet insulation-metal-air interface. The current exposure time is two weeks but may be changed based on the observations. Representative samples of the cellulosic, mineral fiber, and foam insulations are being investigated by the procedure.

Some additional cyclic polarization measurements are being conducted. Examination of some of the previously determined polarization curves indicated that they may not be representative at the iigher current densities because of errors in the plotted potentials due to IR potential offset of the reference electrode relative to the specimen potential. This error is not significant in the interpretation of the curves in the potential/current density range at which corrosion has been observed in the metal/environment systems being studied. However, the error can be important when the entire polarization curve is being measured to determine to characterize the electrochemical behavior of a system. The characterization of this behavior has been a part of the present investigation. 


\title{
6. RESEARCH AND DEVELOPMENT DATA TO DEFINE THE THERMAI \\ PERFORMANCE OF REFLECTIVE MATERIALS USED TO CONSERVE ENERGY IN BUILDINGS
}

\author{
A. O. Desjarlais \\ Thermatest Division of Holometrix, Inc. \\ Cambridge, Massachusetts 02139 \\ ORNL/SUb-SA835/23
}

We cont inue to receive requests for ORNL/Sub/88-SA835/1, but our supply

is exhausted. We are initiating a reproduction order for 50 additional copies.

7. RADIATION CONTROL COATINGS

Robiert W. Anderson

Robert W. Anderson and Associates, Inc. Boulder City, Nevada 89005

ORNL/SUb-SE791/4

The planned exposure panel ( $4 \mathrm{ft}$ by $8 \mathrm{ft}$ ) with a radiation control coating on half of the panel was installed in the Roof Thermal Research Apparatus in July 1990. Two weeks of data from this system have been collected and are being analyzed. The maximum temperatures observed for the panel without the radiation coating exceeded those with the radiatior, coating by over $60^{\circ} \mathrm{F}$. 


\section{Task B3. BUILDING MATERIALS PROGRAM MANAGEMENT SUPPORT}

\section{SUPPORT ACTIVITY - ORNL}

This task is focused on two topics:

(1.1) Exchange of technical results with the building materials community.

(1.2) Coordination of subcontracted research at other facilities.

1.1 Exchange - ORNL

R. S. Graves. ORNL, and D. Wysockt, Mobay, are Co-Chairmen of the ASTM C 16 Second Symposium on Insulation Materials. In August. they organized a tentative program and prepared acceptance letters to the authors and instruction letters for Session Chairmen that were mailed on August 31, 1990. Manuscripts are due January 2, 1990 , to allow the Symposium proceedings to be avallable by october 10,1991 .

H. Alan Fine will make a presentation on powder-filled evacuated panels at the EPA conference on halons in November 1990.

\subsection{Coordination - ORNL}

We are continuing to try to place a subcontract on research on advanced foams. We provided DOE/HQ with a list of potential panel members to revise the Insulation Fact Sheet and to review ZIP 2.0. We returned the galley proofs to MIT on a manuscript that described the Building Materials Program. We are drafting a $r y$ 1991 Statement of Work for DOE/HQ. Galley proofs of C 1044 and C. 1153 were returned to ASTM. 


\section{BUILDING ENVELOPE SYSTEMS}

\section{ORNL Staff:}

J. E. Christian, K. E. Wilkes, R. L. Wendt, G. E. Courville, P. W. Childs, and K. W. Childs

This task includes work done at ORNL and work by others on DOE-funded projects on Building Envelope Systems and is divided into Wall

Performance, Advanced Wa11 Systems, Foundation Systems, Roof Systems, and Building Diagnostics. Each of these project areas is treated separately on the following pages. 


\section{WALL PERFORMANCE}

1. THERMAL MASS SIMPLIFIED DESIGN TOOL ASSESSMENT

J. E. Christian

Oak Ridge National laboratory

Oak Ridge, Tennessee 37831-6070

No progress to report for the month of August. 


\title{
2. DYNAMIC EVALUATION OF THERHAL BRIDGES
}

\author{
D. Burch \\ National Institute of Standards and Technology \\ Gaithersburg, MD
}

ORNL/IA-21513/25

In this study, a finite-difference model is used to predict the steadystate and dynamic (time-dependent) performance of thermal bridges in a typical office butlding. The thermal bridges included in the analysis are a BUR roof with ceiling fasteners, a roof/wall interface, an insulated masonry cavity wall with steel studs, a slab floor penetrating an insulated masonry cavity wall, and a window frame/wall interface. The goal of this project is to analyze the effect of these thermal bridges on the predicted space heating and cooling loads of the typical office building.

Progress Report for July 1990:

Milestone 3 (Prepare Final Report): A final report for the project was prepared that included the following results.

A finite-difference model is used to predict the steady-state and dynamic thermal performance of thermal bridges in a typical office building. The thermal bridges include: a built.-up roof system with ceiling fasteners, a roof/wall interface, an insulated masonry cavity wall with metal studs, a floor slab that penetrates wall insulation, and a window frame/wall interface.

The steady-state analysis reveals that the thermal bridges increased the overall envelope heat transfer coefficient for the office building by $35 \%$. A thermal bridge is found to have a large effect when it has a large cross sectional area that short circuits the thermal insulation of the building envelope.

In the dynamic analysis, a finite-difference model is used to numerically determine a complete set of conduction transfer function (CTF) coefficients for each of the thermal bridges. The mathematical procedure is to predict the heat transfer response of a thermal bridge excited by a ramp excitation function. The heat transfer response for a triangular pulse is subsequently obtained by summing the responses for three ramp excitation functions to form a triangular pulse. A recursive relation employing the common ratio is applied to the triangular-pulse response to determine firs-order CTF coefficients. The validity of the CTF coefficients is demonstrated by accurately predicting the heat transfer response of each of the thermal bridges to a diurnal excitation function. 
An attempt was made to incorporate the numerical CTF coefficients into a building loads computer program, called the Thermal Analysis Research Program (TARP). This effort was unsuccessful.

TARP predicts the heat transfer response at building surfaces using transfer function equations that use surface temperature instead of air temperature as driving force temperatures. This means that the CTF coefficients used in TARP must not include the air film resistances. Yet, in the numerical approach use to determine CTF coefficients, it was essential that reasonable air film resistances be included at both the interior and exterior surfaces. Otherwise, a constant surface temperature is inappropriately imposed as the boundary conditions. After the numerical CTF coefficients were determined, the authors were unable to find a way to remove the effect of the air film resistance from the coefficients. 


\title{
3. VALIDATION OF MOISTURE-TRANSFER MODEL
}

\author{
D. Burch \\ National Institute of Standards and Technology \\ Gaithersburg, Maryland 20899
}

ORNL./IA-21513/25

Progress Report for July 1990:

Milestone 3 (Complete Final Report on Sensitivity Analysis): The final report on the moisture sensitivity analysis is undergoing the editoriai review process at NIST.

The report describes the NIST Moisture Transfer Model that predicis the combined transfer of heat and moisture through multi-layer building construction under non-steady-state conditions. The model includes the effect of vapor diffusion transfer, capillary transfer, and convection transfer (i.e., infiltration and exfiltration). The model can simulate the moisture performance of a wide range of building constructions and uses WYEC weather data as input.

In the report, the mode 1 is subsequentily used to predict the average moisture content in the sheathing and siding of wood-frame cavity wall as a function of time of year. In the analysis, hourly WYEC weather data are used for a mild winter climate (Atlanta, GA), an intermediate winter climate (Boston, MA), and a cold winter climate (Madison, WI) For the analysis, the indoor temperature is maintained at $70^{\circ} \mathrm{F}$, and separate computer runs are carried out for indoor relative humidities of $35 \%$ and $50 \%$.

The effect of several construction parameters on the winter moisture accumulation are investigated. The parameters include the interior vapor retarder permeance, sheathing permeance, exterior paint permeance, indoor air leakage, and the amount of cavity insulation. In addition, a controversial moisture management technique, outdoor ventilation of a cavity between the sheathing and siding, is investigated.

The traditional moisture management techniques of providing a vapor retarder and sealing interior air leakage paths were found to be effective in controlling winter moisture accumulation. However, the technique of outdoor ventilation of a cavity between the sheathing and siding was found to be ineffective.

ORNL funding has just been received and work is just commencing for FY 1990 project work. 


\title{
ADVANCED WALL SYSTEMS
}

\section{MOISTURE CONTROL HANDBOOK \\ Joseph Lstiburek \\ Dames \& Moore, Trow \\ Park Ridge, Illinois 60068 \\ ORNL/SUb-SD350/6}

\begin{abstract}
Several revised drawings based on the August 2, 1990, review have been sent to John Carmody for incorporatinon into the next draft Moisture Control Handbook. Additional detailed comments have been sent to Joseph Lstiburek following the review panel meeting. A revised test is being worked on. This includes the addition of several new sections: wetting and drying rates, HVAC pressurization techniques, and attic and crawl space ventilation. The revisions have not been recieved at ORNL as of September 6, 1990. Several new sections will be added to the next draft.
\end{abstract}




\section{FOUNDATION SYSTEMS}

\section{BUILDING FOUNDATIONS RESEARCH AGENDA}

J. E. Christian

Oak Ridge National Laboratory

Oak Ridge, Tennessee 37831-6070

The first phase of the ESRA construction is almost complete. The door locks have been installed and the HVAC installed and turned on August 23, 1990. A preliminary survey of the inside temperature uniformity indicates the mid-height varies by less than $\pm 2^{\circ} \mathrm{F}$. A quotation has been received to conduct the construction portion of the basement insulation installation and backfilling of the north basement wa11. Heat flux transducers have been obtained and the Data Acquisition system installed in the ESRA. The DAS will ultimately have the capabilities to record more than 260 sensors per scan.

\section{SLAB FOUNDATION BENCHMARK MODEL}

D. Wasserman and Jeff Christian

Oak Ridge National Laboratory Oak Ridge, Tennessee 37831-6070

David Wasserman is completing the Users manual and parts of the comparison study of the model to the slab data. 
3. FOUNDATION THERMAL PERFORMANCE SIMPLIFIED PREDICTION TOOL

\section{Jeff Christian}

Oak Ridge National Laboratory

Oak Ridge, Tennessee 37831-6070

A punch list has been made up for completion of The Builders Foundation Handbook as a result of the DOE review on August 2, 1990. The additional work has required inttiation of an extension to the subcontract with John Carmody. 
ROOF SYSTEMS

\title{
1. ROOFING RESEARCH CENTER
}

\author{
R. L. Wendt \\ Oak Ridge National Laboratory \\ Oak Ridge, Tennessee 37831-6070
}

Activities at the Center included a recheck of the calibration of the Large Scale Climate Simulator (LSCS, Item 2, following) after the completion of the initial series of tests with the Attic Test Module which investigated convective heat loss through low-density, loose-fill fibrous glass insulation and the evaluation of vartous means to mitigate this phenomena. This recheck showed no change in readings from those obtained before attic testing at the colder temperatures at which convection was observed. A draft paper describing the findings of our investigation of convective heat loss was distributed to members of the Technical Committee of the Mineral Insulation Manufacturers Association for their comments. Several comments have been received and a meeting with one manufacturer is planned to discuss our findings in detail. Several manufacturers have expressed interest in the possibility of testing other products under similar environmental conditions in the LSCS.

Work neared completion on the Roof Mechanical Properties and Foundation Research Apparatus (Item 8).

A test panel to evaluate reflective coatings was installed on the Roof Thermal Research Apparatus (RTRA) in early July and continues to be monitored (see Task B2, Item 7). This panel consists of a $1 \frac{1}{2}$ in. uninsulated plywood deck covered with a black EPDM membrane. Half of the panel was coated with a commercial reflective coating with a thickness of $30 \mathrm{mils}$, the remainder remained uncoated. 


\section{LARGE SCALE CLIMATE SIMULATOR}

\section{P. W. Childs, K. E. Wilkes, and T. W. Petrie \\ Oak Ridge National Laboratory \\ Oak Ridge, Tennessee 37831-6070}

Testing of the Attic Seal products was completed. Final data analysis is currently under way.

The Attic Test Apparatus was removed from the LSCS and the calibration sample was reinserted. During removal of the attic specimen, the metering chamber gasket was damaged. The existing open-cell foam gasket was replaced with a $1 / 4$ in. thick closed-cell neoprene gasket. This new material provided an improved seal around the perimeter of the metering chamber.

Runs were made on the calibration sample duplicating runs made on the Attic Seal test. The expanded polystyrene used in the calibration sample appeared to warp at higher temperature $\left(120^{\circ} \mathrm{F}\right.$ in the climate chamber) and pull away from the metering chamber gasket near the corners. Tape was applied around the gasket perimeter to stop infiltration. The results were in good agreement with the known values of the calibration sample.

The Attic Test Apparatus was reinserted to confirm whether the gypsum warped at the higher temperatures like the polystyrene. The gypsum did not warp at temperatures as high at $145^{\circ} \mathrm{F}$ in the climate chamber.

\section{IEA ANNEX 19 ON LOW SLOPE ROOF SYSTEMS}

George E. Courville

Oak Ridge National Laboratory

0ak Ridge, Tennessee 37831-6070

No proumess to report for the month of August. 


\section{ATTIC TESTING IN THE LSCS \\ Kenneth E. Wilkes and Agnes Delmas \\ Oak Ridge National Laboratory \\ Oak Ridge, Tennessee 37831-6070}

Testing of low-density loose-fill fiberglass insulation in the Attic Test Module was completed in July. Dita from these tests have been analyzed and a report to the Attic Seal Corp. is being prepared.

The attic was removed from the LSCS and the expanded polystyrene foam caltbration panel was installed. A series of tests has beell performed with this panel to assist in determining the uncertainty of the attic results. It was found that under simulated summer conditions, the foam panel warped due to differential thermal expansion, creating a small gap between the metering chamber and the pane1. Tests under this condition resulted in an $R$-value that was 20 to 25 percent lower than the known value. After sealing this gap, the measured R-value was within a few percent of the known value. Under simulated winter conditions, differential thermal expansion caused the parel to try to warp in the opposite direction, resulting in a good seal between the metering chamber and the panel. Under winter conditions, measured R-values were within 3 to 9 percent of the known value. The foam panel has been removed and the attic data were also affected by warping of the ceiling. 


\title{
5. FIELD TESTING OF ISOCYANURATE FOAMS WITH ALTERNATE BLOWING AGENTS
}

\author{
J. E. Christian and G. E. Courvilile \\ Oak Ridge National Laboratory \\ Oak Ridge, Tennessee 37831-6070
}

The Data Acquisttion System has been permanently installed in the ESRA and the six instrumented panels in the roof have been hooked-up. The six panels are equipped with caltbrated heat flux transducers and thermocouples. Three are installed in the BUR with insulation samples blown with CFC-11, HCFC-123 and HCFC-141b. The other three samples are installed under the fully adhered single-ply EPDM in samples blown with
CFC-11, HCFC-123 and HCFC-141b.

Some analysis of the six panels installed in the RTRA is revealing a leveling of the thermal drift throughout the summer months, despite the higher mean insulation temperatures during this period. This is probably explained by the fact that the 1.5 inch boards are approaching a full year since production and the majority of the air component gas diffusion is believed to be complete. The blowing agent diffusion rate is considerably slower and will dominate the underlying cause of aging
for the remainder of the tests.

The paper for the 33rd Annual Polyurethane Conference on the analys is of the RTRA data has been edited by SPI, reviewed by the ORNL authors, and sent back for final placement on galleys. Slides are being developed for this presentation, which will be given on October 2, 1990.

The work statement for the second batch of EPA funds has been prepared and a contract developed and approved by both EPA and DOE. The funds from EPA have not arrived as of this writing.

The work statement for adding the blends has been sent to Carl Wangman, PIMA, for their approval. This is the first step in the development of a contract between ORNL and PIMA to transfer the PIMA funds to ORNL. This contract will follow a new, improved procedure for much easier. transfer of funds into the Laboratory, called CRADAs. 


\title{
6. ROOF MECHANICAL PROPERTIES RESEARCH APPARATUS \\ Robert L. Wendt \\ Oak Ridge National Laboratory \\ oak Ridge, Tennessee 37831-6070
}

The roof containing the five different polyisocyanurate insulation formulations was installed June 26-27, 1990. A single, approximately $2 \mathrm{ft}$ diameter, bitster was first noted on August 3. Another $2 \mathrm{ft}$ diameter blister was noted on August 13. The bltsters are located in the bullt-up roof section on two insulation boards made of the HCFC123 /HCFC-141b 50/50 blend and located in the configuration with the insulation facers perforated and plys applied direct to insulation. The cause of these blisters (workmanship andior material) is unknown at this time and will not be determined until samples are taken and analyzed at the cunclusion of the test period.

Also noted during this period was the development of a number of "fish mouths" on the BUR portion of the roof platform. One of these is in close proximtty to the second blister. The under surface of the deck has been inspected and no evidence of leaking was found.

other work on the project included the relocation of a high voltage power line that crosses the facility and the provision of electric power to the structure. The HVAC system was started on August 23. Work remaining to be accomplished includes site grading, and the installation of the initial series of foundation experiments.

\section{ROOFING INDUSTRY COMMITTEE ON WIND ISSUES}

\author{
George E. Courville \\ Oak Ridge National Laboratory \\ Dak Ridge, Tennessee 37830-6070
}

No progress to report for the month of August. 


\title{
D. COOPERATIVE PROJECTS
}

\section{COOPERATIVE INDUSTRY/GOVERNMENT RESEARCH PROJECT ON ALTERNATIVE BLOWING AGENTS}

\author{
G. E. Courvilie, D. L. McElroy, J. E. Chrístian, and R. L. Wendt \\ Oak Ridge National Laboratory \\ Oak Ridge, Tennessee 37831
}

This project is jointly supported by the Department of Energy, the Environmental Protection Agency, The Soctety of the Plastics Industry, the Polyisocyanurate Insulation Manufacturers Assoctation, and the National Roofing Contractors Association. The objective of the project is to conduct comparat ve laboratory and field studies of isocsanurate foam roofing boards blown with conventional CFC-11 and with alternative blowing agents. The purpose is to identify performance differences, if any, between foams with alternattve blowing agents and foall blown with CFC -11 .

1. MEETINGS AND PRESENTATIONS

None.

2. LABORATORY TESTING

We circulated a letter report to the participants on the interlaboratory comparison of apparent thermal conductivity measurements at $75^{\circ} \mathrm{F}$ on two rigid polyisocyanurate boards, and as a pair, using four $24 \mathrm{in}$, by $24 \mathrm{in}$. comparative heat flow meter apparatuses that meet ASTM C 513. The impreciston, defined as two standard deviations, was less than that found for a glass fiber blanket in the 1987 ASTM C 687 round robtn. This suggests that future tests should include test specimens with greater thicknosses.

We obtained the MIT computer program for aging and modified it. for use at ORNL at MITB. MITB and programs to calculate the $k$ of gas mixtures provided predictions of long-term foam behavior with alternate permeability values, as a function of board thickness, and for alternative initial blowing agent gas pressure. This showed the need to develop a three-dimensional model to assess aging of faced foams.

\section{FIELD TESTING}

The Data Acquisition System has been permanentily installed in the ESRA and the six instrumented panels in the ruof have been hookedup. The six panels are equipped with callbrated heat. flux transducers and thermocouples. Three are installed in the BUR with insulation samples blown with CFC-11, HCFC-123 and HCFC-141b. The other three samples are installed under the fully adhered single-ply EPDM in samples blown witli CFC-11, HCFC-123 and HCFC-141b. 
Some analysis of the six panels installed in the RTRA is revealing a leveling of the therimal drift throughout the summer manths, despite the higher mean insulation temperatures during this pertod. This is probably explained by the fact that the 1.5 inch boards are approaching a fill1 year stnce production and the majortty of the air component gas diffusion is belteved to be complete. The blowing agent diffusion rate is considerably slower and will dominate the underlying cause of aging for the remalnder of the tests.

\section{ROOF MECHANICAL. PROPERTIES RESEARCH APPARATUS}

The roof containing the five different polytsocyanurate insulation formulations was installed June 26-27, 1990. A single, approximately $2 \mathrm{ft}$ diameter, bitster was first noted on August 3. Another $2 \mathrm{ft}$ diameter bilster was noted on August 13. The bilsters are located in the butlt-up roof section on two insulation boards made of the HCFC-123/HCFC-141b 50/50 blend and located in the conftguration with the insulation facers perforated and plys applied direct to insulation. The cause of these blisters (workmanship and/or material) is unknown at this time and will not be determined until samples are taken and andyzed at the concluston of the test pertod.

Also noted during this period was the development of a number of "fish mouths" on the BUR portion of the roof platform. One of these is in close proximity to the second blister. The under surface of the deck has been inspected and no evtdence of leaking was found.

Other work on the project included the relocation of a high voltage power line that crosses the factlity and the provision of electric power to the structure. The HVAC system was started on August 23. Work remaining to be accomplished includes site grading, and the installation of the initial series of foundation experiments. 

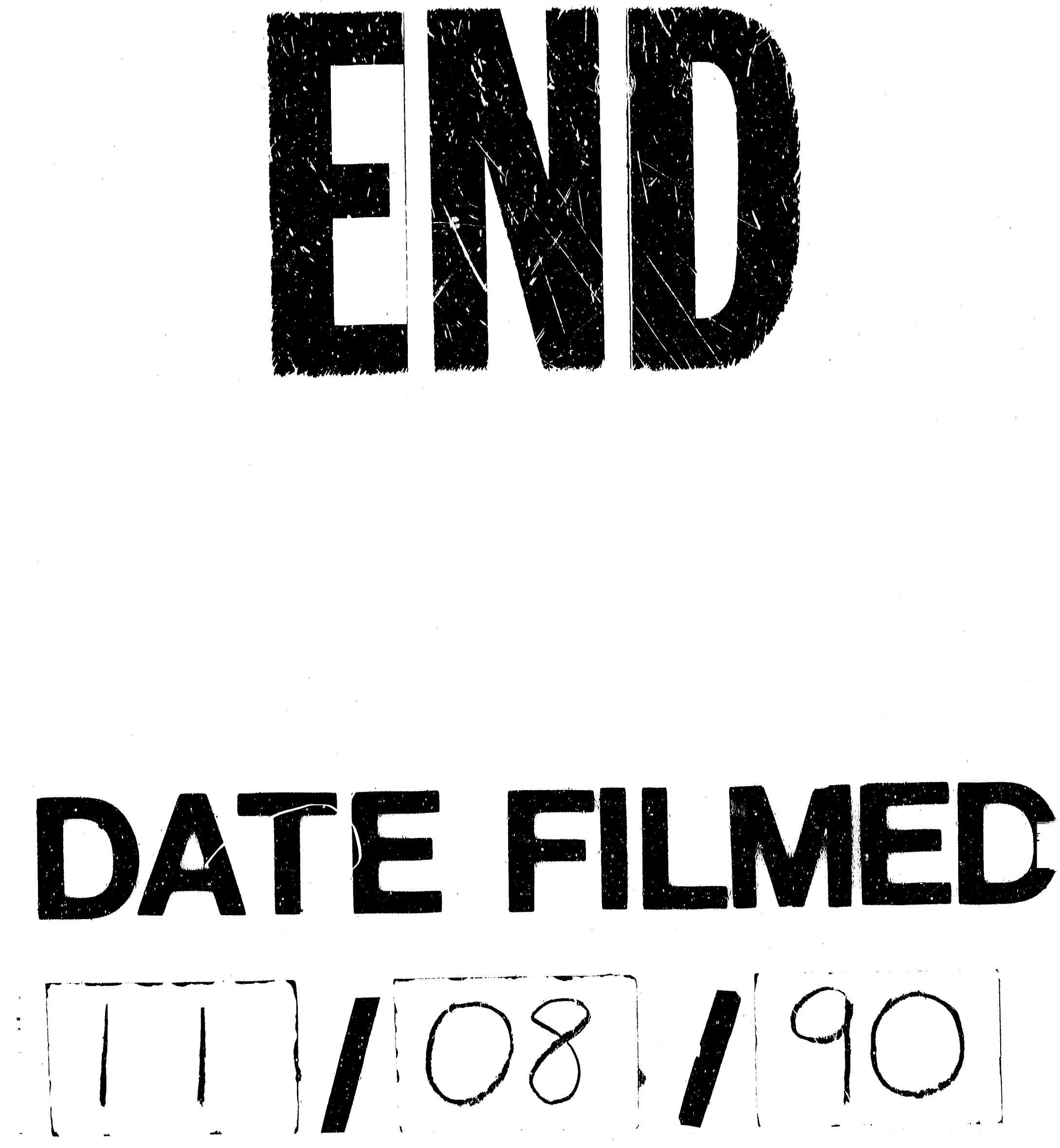
